\title{
HEALTHY BREAKFAST EDUCATION FOR PRIMARY SCHOOL CHILDREN IN PURWOKERTO
}

\author{
Nindy Sabrina $^{1 *}$, Khoirul Anawar ${ }^{1}$, Aviani Harvika ${ }^{2}$, Febry Surbakti ${ }^{1}$, Hardinsyah Hardinsyah ${ }^{1}$ \\ ${ }^{1}$ Nutrition Program, University of Sahid Jakarta, ${ }^{2}$ Nutrition Program, Bogor Agricultural University \\ *nindy_sabrina@usahid.ac.id
}

\begin{abstract}
The prevalence of school children who skipped breakfast is ranged from $17 \%$ to $59 \%$. This fact shows how low the awareness of adequate nutrition in school students is. The aims of this program were to encourage breakfast habit among primary school children (PSC). The breakfast education program was conducted at five primary schools in Purwokerto through trained facilitators, include teachers, in collaboration with PERGIZI PANGAN Indonesia and PT Indofood CBP Sukses Makmur Tbk from 2015 to 2017. The theme of this program was "Healthy Breakfast and Safe Snack for Healthier and Smarter Generation". The number of students participated in this program every year was about 1250 PSC from 3rd grade to 6th grade. The material given for breakfast education program was about healthy breakfast and safe snack, which was bundled as an interesting comic. The breakfast education was given every year, in which a portion of fried noodle with egg and green vegetable plus mineral water and milk was given to each PSC at the day of breakfast program. Data on breakfast habit of PSC were collected at every year before education started. The results showed that 15 teachers for each school already trained and they are expected to be future healthy breakfast educator in each school. The percentage of PSC had breakfast in 2015 was $55.7 \%$ then increased to be $67.9 \%$ in 2016 and $75.3 \%$ in 2017. This implies that a school breakfast education using comic and trained teachers improve PSC breakfast behavior.
\end{abstract}

Keywords: Breakfast education, Nutrition education, School children, Skipped breakfast.

\section{INTRODUCTION}

Breakfast is the regular morning activity which contributes $25 \%$ energy of the day. Children who regularly consume breakfast looks like to have better energy adequacy, macronutrient, and nutritional status than who like to skip breakfast (Dubois, Girard, Potvin Kent, Farmer, \& TatoneTokuda, 2009). Skipping breakfast means as not eating the meal in the morning. The prevalence of primary school children who were stunting, underweight, and overweight in Indonesia was about $35.8 \%$, $11 \%$ and $19.2 \%$, respectively (Kesehatan \& RI, 2013). This may relate to the prevalence of school children who skipped breakfast which could be the cause of malnutrition. Skipping breakfast recently been suggested as potentially affect the snacking habit which contributes to obesity (Huang, Hu, Fan, Liao, \& Tsai, 2010). Breakfast has a beneficial effect not only for the body but also the brain. Earlier studies found that eating breakfast was associated with children's cognitive performance including memory and attention, which affect the student's school performance (Wesnes, Pincock, Richardson, Helm, \& Hails, 2003). Besides, children who skipped breakfast are more likely to be less active than who eat breakfast in the morning (Sandercock, Voss, \& Dye, 2010). Establishing habitual breakfast in primary school children may improve long-term health.

Education plays a key role to determine the people's behavior. Lack of nutrition education in the family is associated with children breakfast skipping behaviour (Keski-Rahkonen, Kaprio, Rissanen, Virkkunen, \& Rose, 2003). The changes knowledge, attitude, and practices could change the children's habit of skipping breakfast (Waisbord, 2014). Most of the day, children spend their time studying in the school. A school could be the place to communicate the health promotion including health breakfast behavior. One of the teaching aids to educate the student is comic. Comic displays text and picture that 
can improve the learning interest of the student (Arini, Choiri, \& Sunardi, 2016). Therefore, the researchers try to give education about healthy breakfast using comic as selected media for the student.

\section{THEORETICAL FRAMEWORK}

Figure 1 shows how nutrition education can influence factors that can impact children nutritional status and cognitive. The student characteristics, social, economy, culture, and education background affect the food habit (Fismen et al., 2016). Breakfast becomes a daily routine for some people, but some people are not. Parents as food provided at home are powerful to socialize the family diet and feeding practice (Hardy, Wadsworth, \& Kuh, 2000). The inherit pattern from parents who do not have breakfast habit will make an assumption for the children that breakfast is not the first priority before going to school. The first thing to change people awareness and motivation is from nutrition education. Nutrition education that teaches positive dietary message may enhance nutrition knowledge and improve dietary behaviour (Raby Powers, Struempler, Guarino, \& Parmer, 2005).

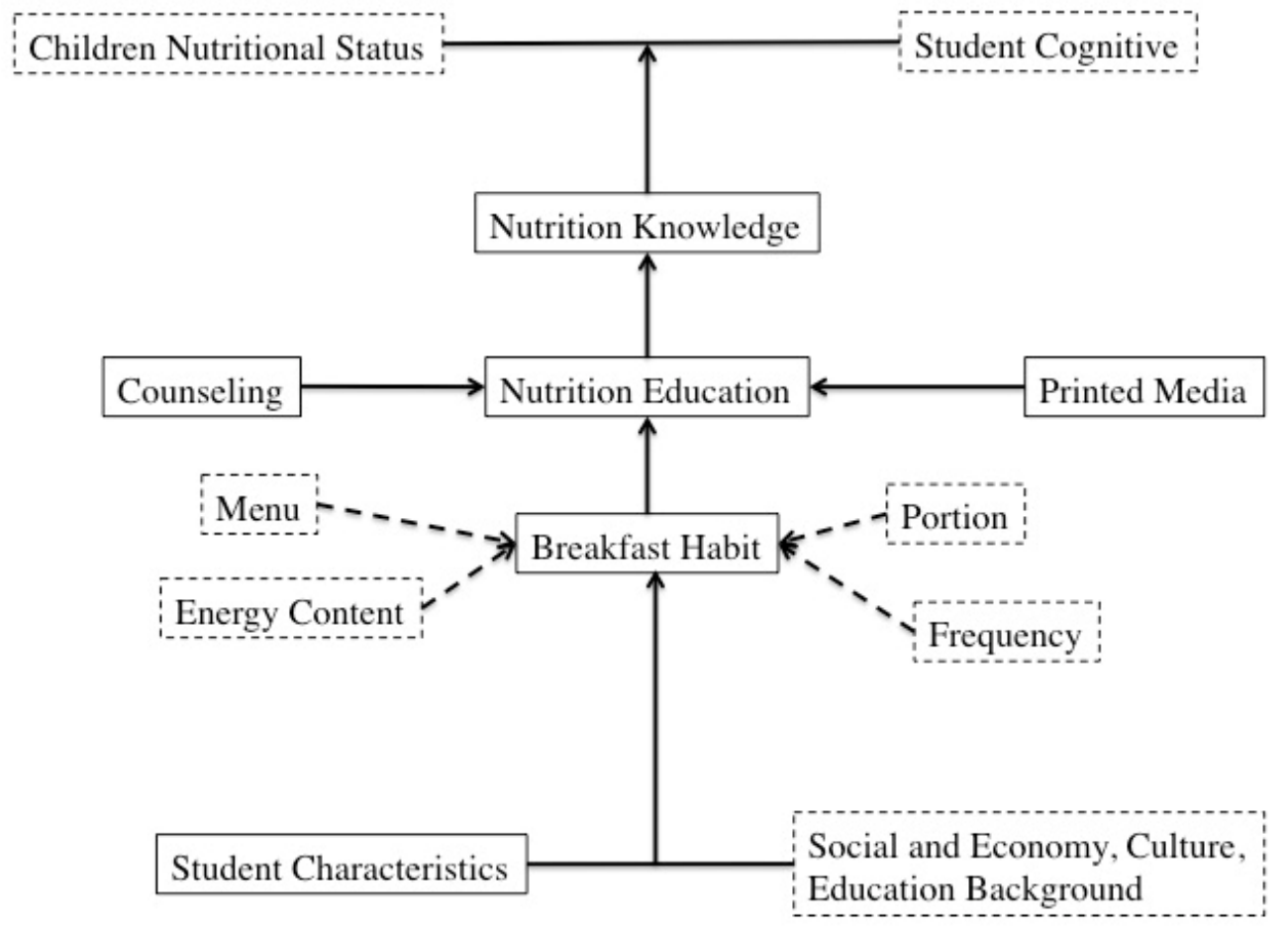

Figure 1. The Theoretical Framework of Breakfast Education Program.

\section{METHOD}

\section{Design and Participants}

The project was conducted from 2015 to 2017 in Purwokerto, East Java, Indonesia. PERGIZI PANGAN Indonesia in collaboration with PT. Indofood CBP Sukses Makmur Tbk conducted healthy breakfast education program with theme "Healthy Breakfast and Safe Snack for Healthier and Smarter Generation". A total of 1250 students from third grade to sixth grade in four schools (SDN (Sekolah Dasar Negeri) Pabuwaran 2, SDN Ledug, SDN Pliken 1, SDN Pliken 2 were invited to participate in this program. One lecturer from university partner and one health community center (Pusat Kesehatan masyarakat (PUSKESMAS)) officers nearby were invited to supervise the programs in each school. All baseline data were collected through the self-administered questionnaires in 2015 before the implementation of the healthy breakfast education program. The study used a 12-month follow-up in 2016 and 2017 to obtain the result. 


\section{Facilitator Training}

PERGIZI PANGAN Indonesia gave a special training to nutrition students who will be the facilitators in the selected schools and the teacher. The materials given were about 1 ) healthy breakfast purposes and benefits 2) breakfast problem in students 3) safety snack guide 4) breakfast problem solving 5) healthy breakfast alternative 6) balanced nutrition visualization 7) frequently question about instant noodle. The facilitators involved in simulation after presentation and discussion session. A total of ninety-four facilitators A total of ninety-four facilitators participated in this program.

\section{Breakfast Preparation}

The breakfast time was started at $7 \mathrm{am}$. The breakfast meals included fried noodle with egg, threespoon table of green vegetables, a cup of mineral water and one carton of milk were given in a paper box in the morning. The calorie of meals was about $500 \mathrm{kcal}$ and eighteen-gram protein. The breakfast meals were prepared in a booth by the facilitator and PT Indofood CBP Sukses Makmur which had high quality and safety of the production process.

\section{Assessment}

The questionnaire that assesses breakfast habit was used. The response of the students was written by facilitators to know the number of students likes to have breakfast and food preference. The baseline questionnaires were given in 2015 and continue in 2016 and 2017 to know the follow-up result.

\section{Education Program}

The education was given after breakfast and questionnaire filling. Two facilitators accompanied by one teacher in each class. This program was carried out with counseling methods using interesting comic, which explained balanced nutrition and healthy breakfast. Counseling was conducted by nutrition students as facilitators and organized by the PERGIZI PANGAN Indonesia. The students read the comic and three to four students retold the story in front of the class.

\section{RESULT AND DISCUSSION}

The project had been done in three years from 2015 to 2017. The education for students started from $7 \mathrm{am}$ to $9 \mathrm{am}$ in the classroom. The event was started with hand washing and praying and followed by breakfast together. In figure 2, the prepared menu for breakfast was fried noodles, vegetables, and fried eggs, which packed in the paper box. There was a bottle of milk for drinking. Instant noodle had been chosen as a staple food in this program because it has an affordable price, convenience, has a good flavor, and safe. Noodle with fortification could be a potential intervention in improving nutritional properties(Gulia, Dhaka, \& Khatkar, 2014). An egg was put in the box as protein source food. Beside eggs are an inexpensive, it provides 18 vitamin and minerals including omega 3 (Fraeye et al., 2012). Three-spoon of vegetables had been prepared to fulfill fiber needs. Overall, the students and teachers liked the breakfast menu during the event as shown in figure 3. However, some students felt that the number of vegetables was not enough. 


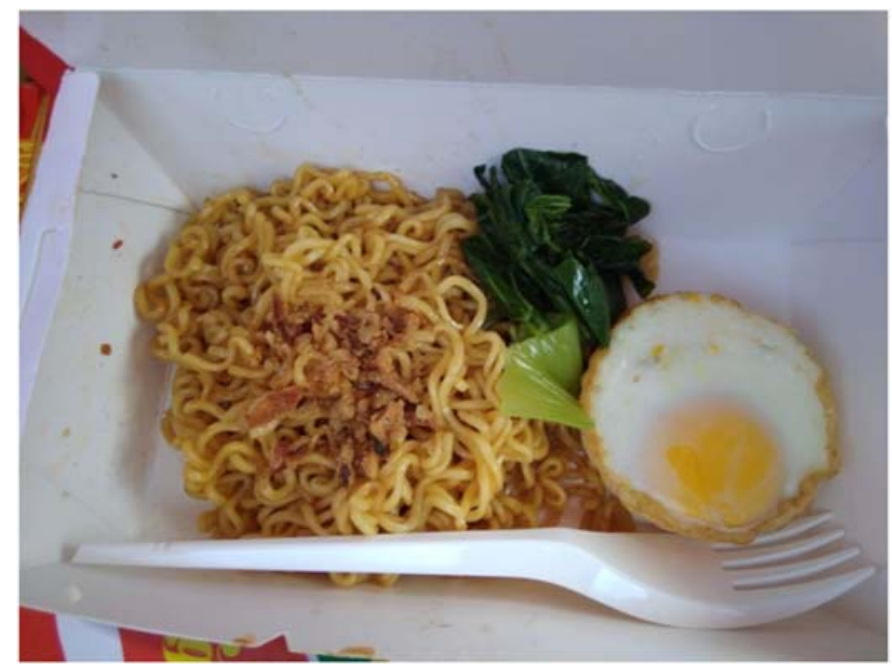

Figure 2. Prepared menu for breakfast program.

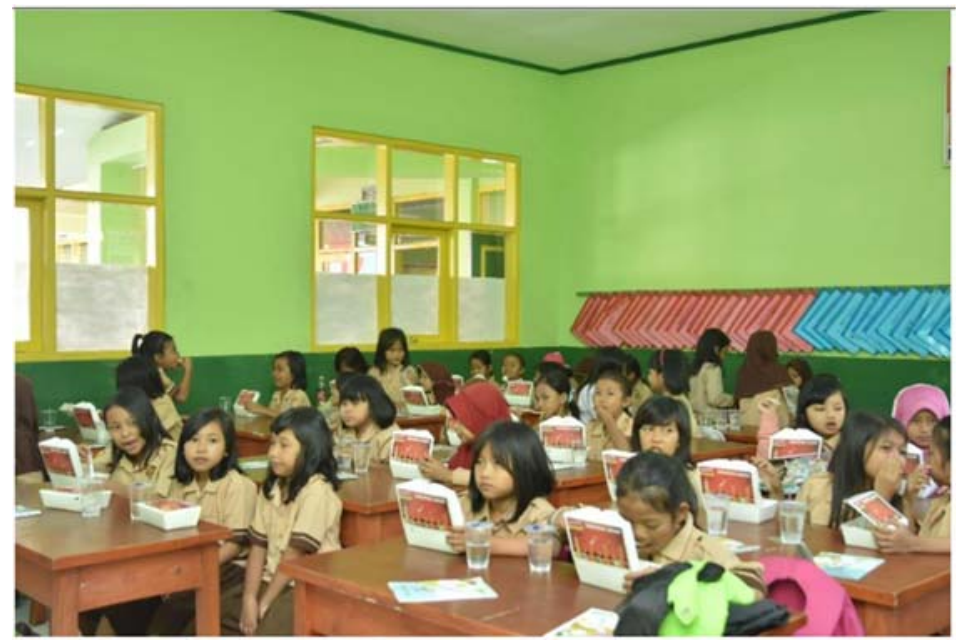

Figure 3. All students eat the breakfast.

After breakfast, a facilitator accompanied by a teacher, giving a nutrition counseling and education using comic. The students looked interested to read the comic as shown in figure 4 . The title of the comic was "Ayo Sarapan Sehat". There were four characters in the comic including Aldi, Wikan (Aldi's friend), Aldi's mom, and teacher. The story told about a primary school student named Wikan who did not want to eat breakfast then he got sick at the school. The teacher in the comic explains how important the breakfast is, the benefits of breakfast, and nutrition balanced diet picture. The nutrition balanced diet picture was described in the comic for socializing the nutrition message to prevent malnutrition. The nutrition balanced diet picture covers some messages such as consuming various food, keeping hygiene, doing a regular physical activity, and maintaining the body weight(Soekirman, 2011). 


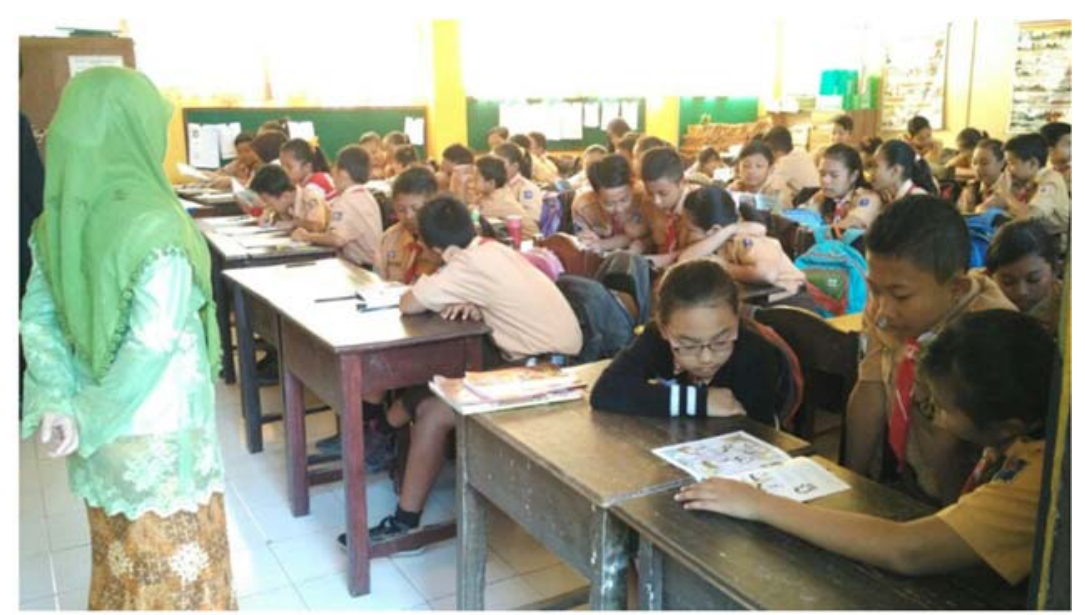

Figure 4. The students read “Ayo SarapanSehat” comic.

The questionnaire data was collected to know the breakfast habit program progression. Figure 5 illustrates the number of students who like to breakfast as the percentage observed across grades at Purwokerto. Overall, the percentage of breakfast habit increased over the period given except grade third and grade fifth. In 2016, grade third data showed an increase of about 23\% from 2015 then decrease slightly in 2017. The possible cause of the reduced number was because the students still in the second grade at that time and did not obtain the breakfast education yet. There was no significant difference in breakfast data in fifth grade over the years. This increased data shows that comic could be used as media to increase nutrition education among students. The comic can provide self-awareness, reassurance, empathy, and companionship in exploring the impact of illness (McNicol, 2017).

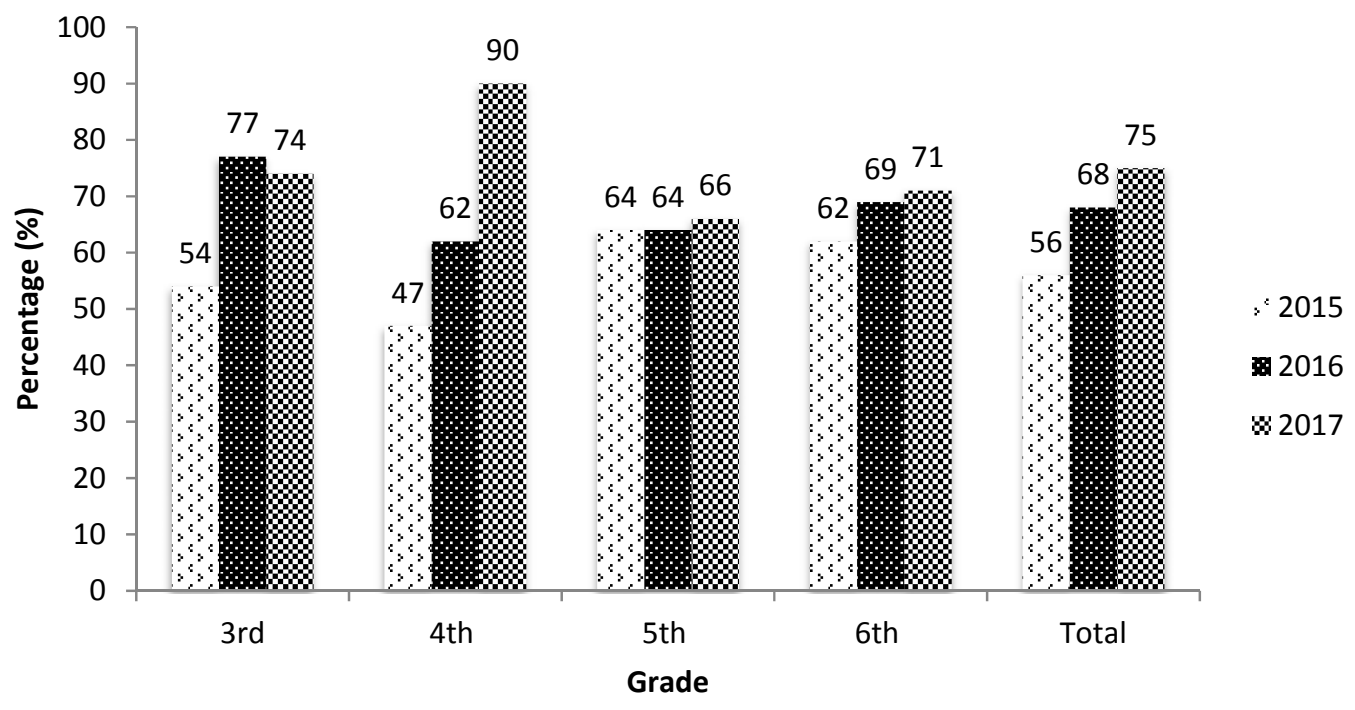

Figure 5. Percentage of students who had regular breakfast based on grade

Figure 6 shows the trend of breakfast habit based over the years. Overall, the number of students who had breakfast habit rose consistently from 2015 to 2017. It may because of the teacher's role who can encourage the students to get used to breakfast regularly. The teacher is a role model for the students. Role modeling in the school setting is described by the student's motivation to obtain insight, knowledge, and values from the teacher (Bahman Bijari et al., 2016). When the teacher asked the student for having breakfast regularly, the student will easy to follow the teacher's advice. This was also strengthened by the enthusiasm of teachers during the education process. 


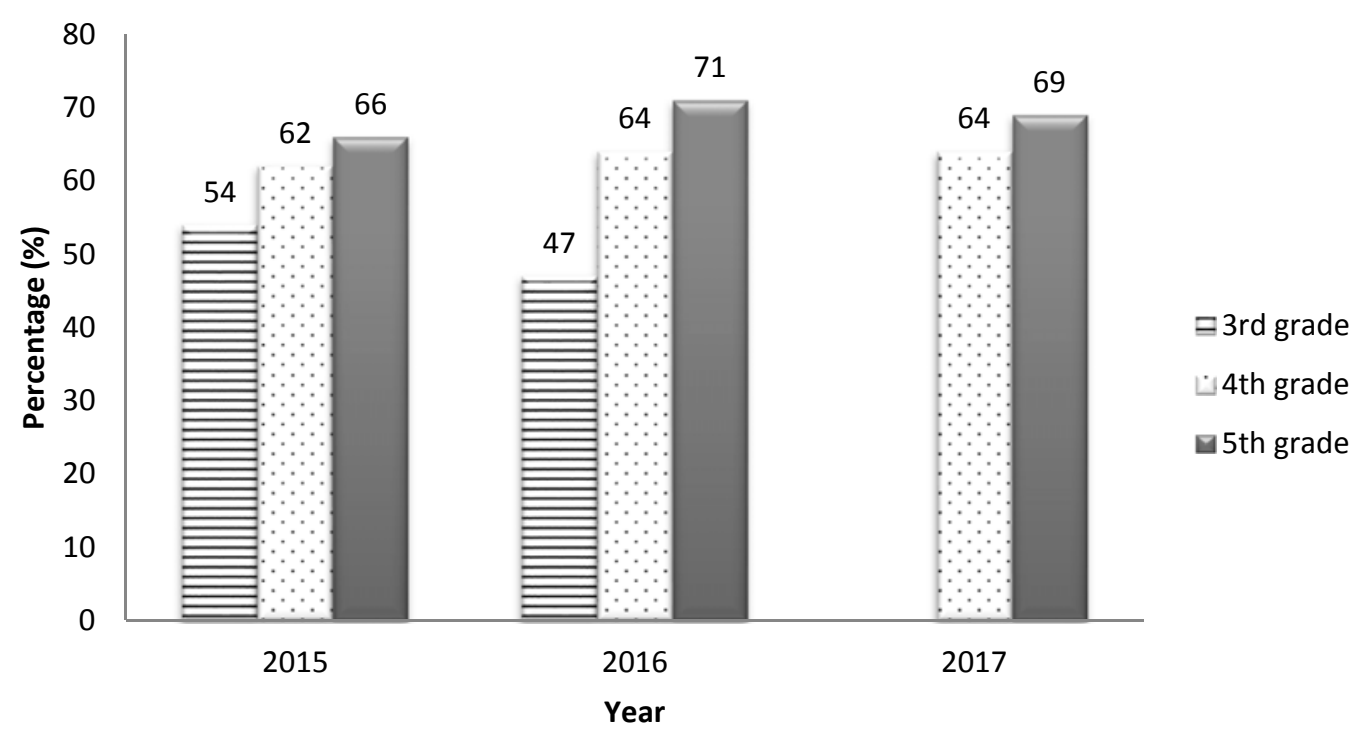

Figure 6. Percentage of students who had regular breakfast across the year.

The questionnaire not only asked about breakfast habit but also about student's food preference. The questionnaire result reveals that the percentage of student who did not like to eat vegetable increased from $6.7 \%$ in 2015 to $8.4 \%$ in 2016 then decreased to $6.3 \%$ in 2017. The average percentage of vegetable consumption was about $7 \%$. Likewise, the student who did not like to eat fruit was less than $5 \%$ and who did not like to eat an egg was about $2 \%$ to $6 \%$. Eggs are the protein source food which affordable and easy to get which possible to put it as additional food in breakfast menu to enrich the nutrition. The data also shows the percentage of students who did not like to eat noodle is less than $2 \%$. Noodle becomes the second staple food after rice in Indonesia. It is not a surprise if the most of the students like to eat noodle. The low percentage of students who did not like to drink milk explains that milk could be an additional drink to enhance nutrition in students. Table 1 also shows the data about stomach pain feeling when the students eat some kinds of food. There were no a significant findings of stomach pain feeling in any kind of food. This implies that there was no cultural burden or eating difficulties among students if they insist to do regular breakfast with various foods.

Table 1. The prevalence of the students based on preference food in primary school.

\begin{tabular}{|c|c|c|c|c|c|c|c|}
\hline \multirow{2}{*}{ No. } & \multirow{2}{*}{ Items } & \multicolumn{2}{|c|}{2015} & \multicolumn{2}{|c|}{2016} & \multicolumn{2}{|c|}{2017} \\
\hline & & $\mathrm{n}$ & $\%$ & $\mathrm{n}$ & $\%$ & $\mathrm{n}$ & $\%$ \\
\hline 1 & $\begin{array}{l}\text { Number of students who had } \\
\text { regular breakfast }\end{array}$ & 390 & 55.7 & 477 & 67.9 & 552 & 75.3 \\
\hline 2 & $\begin{array}{l}\text { Number of students who bring } \\
\text { lunch to school }\end{array}$ & 59 & 8.4 & 39 & 5.6 & 10 & 1.4 \\
\hline 3 & $\begin{array}{l}\text { Number of students who did } \\
\text { not like to eat vegetable }\end{array}$ & 47 & 6.7 & 59 & 8.4 & 46 & 6.3 \\
\hline 4 & $\begin{array}{l}\text { Number of students who did } \\
\text { not like to eat fruit }\end{array}$ & 19 & 2.7 & 20 & 2.8 & 19 & 2.6 \\
\hline 5 & $\begin{array}{l}\text { Number of students who did } \\
\text { not like to eat egg }\end{array}$ & 19 & 2.7 & 41 & 5.8 & 23 & 3.1 \\
\hline 6 & $\begin{array}{l}\text { Number of students who did } \\
\text { not like to eat noodle }\end{array}$ & 0 & 0 & 12 & 1.7 & 0 & 0 \\
\hline 7 & $\begin{array}{l}\text { Number of students who did } \\
\text { not like to drink milk }\end{array}$ & 3 & 0.4 & 4 & 0.6 & 3 & 0.4 \\
\hline 8 & $\begin{array}{l}\text { Number of students who did } \\
\text { not like to drink drinking water }\end{array}$ & 1 & 0.1 & 3 & 0.4 & 0 & 0 \\
\hline
\end{tabular}




\begin{tabular}{|c|l|c|c|c|c|c|c|}
\hline \multirow{2}{*}{ No. Items } & \multicolumn{2}{|c|}{2015} & \multicolumn{2}{c|}{2016} & \multicolumn{2}{c|}{2017} \\
\cline { 3 - 7 } & \multicolumn{1}{|c|}{$\mathrm{n}$} & $\%$ & $\mathrm{n}$ & $\%$ & $\mathrm{n}$ & $\%$ \\
\hline 9 & $\begin{array}{l}\text { Number of students who feel } \\
\text { stomach pain when eating } \\
\text { vegetable }\end{array}$ & 1 & 0.1 & 6 & 0.9 & 1 & 1 \\
\hline 10 & $\begin{array}{l}\text { Number of students who feel } \\
\text { stomach pain when eating fruit }\end{array}$ & 1 & 0.1 & 0 & 0 & 0 & 0 \\
\hline 11 & $\begin{array}{l}\text { Number of students who feel } \\
\text { stomach pain when eating egg }\end{array}$ & 11 & 1.6 & 12 & 1.7 & 13 & 13 \\
\hline 12 & $\begin{array}{l}\text { Number of students who feel } \\
\text { stomach pain when eating } \\
\text { noodle }\end{array}$ & 2 & 0.3 & 3 & 0.4 & 1 & 1 \\
\hline 13 & $\begin{array}{l}\text { Number of students who feel } \\
\text { stomach pain when drinking } \\
\text { milk }\end{array}$ & 2 & 0.3 & 9 & 1.4 & 11 & 1.5 \\
\hline
\end{tabular}

\section{CONCLUSION}

Based on the project results can be concluded that the breakfast behavior among students could be improved by using interesting media such as comic. Moreover, the trained teacher as a role model for students could encourage the students to get used to having breakfast regularly. The future menu for breakfast could be obtained from questionnaire data.

\section{ACKNOWLEDGEMENT} Makmur.

This activity was supported by PERGIZI PANGAN Indonesia and PT Indofood CBP Sukses

\section{REFERENCES}

Arini, F. D., Choiri, A. S., \& Sunardi, S. (2016). THE USE OF COMIC AS A LEARNING AID TO IMPROVE LEARNING INTEREST OF SLOW LEARNER STUDENT. European Journal of Special Education Research.

Bijari, B. B., Zare, M., Haghdoost, A. A., Bazrafshan, A., Beigzadeh, A., \& Esmaili, M. (2016). Factors associated with students' perceptions of role modelling. International journal of medical education, $7,333$.

Dubois, L., Girard, M., Kent, M. P., Farmer, A., \& Tatone-Tokuda, F. (2009). Breakfast skipping is associated with differences in meal patterns, macronutrient intakes and overweight among preschool children. Public health nutrition, 12(1), 19-28.

Fismen, A. S., Smith, O. R. F., Torsheim, T., Rasmussen, M., Pagh, T. P., Augustine, L., ... \& Samdal, O. (2016). Trends in food habits and their relation to socioeconomic status among Nordic adolescents 2001/2002-2009/2010. PloS one, 11(2), e0148541.

Fraeye, I., Bruneel, C., Lemahieu, C., Buyse, J., Muylaert, K., \& Foubert, I. (2012). Dietary enrichment of eggs with omega-3 fatty acids: A review. Food Research International, 48(2), 961-969.

Gulia, N., Dhaka, V., \& Khatkar, B. S. (2014). Instant noodles: processing, quality, and nutritional aspects. Critical reviews in food science and nutrition, 54(10), 1386-1399. 
Hardy, R., Wadsworth, M., \& Kuh, D. (2000). The influence of childhood weight and socioeconomic status on change in adult body mass index in a British national birth cohort. International journal of obesity, 24(6), 725.

Huang, C. J., Hu, H. T., Fan, Y. C., Liao, Y. M., \& Tsai, P. S. (2010). Associations of breakfast skipping with obesity and health-related quality of life: evidence from a national survey in Taiwan. International journal of obesity, 34(4), 720.

Kesehatan, K., \& RI, K. K. (2013). Riset kesehatan dasar. Jakarta: Badan Penelitian dan Pengembangan Kesehatan Departemen Kesehatan Republik Indonesia.

Keski-Rahkonen, A., Kaprio, J., Rissanen, A., Virkkunen, M., \& Rose, R. J. (2003). Breakfast skipping and health-compromising behaviors in adolescents and adults. European journal of clinical nutrition, 57(7), 842.

McNicol, S. (2017). The potential of educational comics as a health information medium. Health Information \& Libraries Journal, 34(1), 20-31.

Raby, P.A., Struempler, B. J., Guarino, A., \& Parmer, S. M. (2005). Effects of a nutritioneducation program on the dietary behavior and nutrition knowledge of second-grade and third-grade students. Journal of school health, 75(4), 129-133.

Sandercock, G. R., Voss, C., \& Dye, L. (2010). Associations between habitual school-day breakfast consumption, body mass index, physical activity and cardiorespiratory fitness in English schoolchildren. European journal of clinical nutrition, 64(10), 1086.

Soekirman. (2011). Taking the Indonesian nutrition history to leap into betterment of the future generation: development of the Indonesian Nutrition Guidelines. Asia Pacific Journal of Clinical Nutrition, 20(3), 447-451.

Waisbord, S. (2014). Where do we go next? Behavioral and social change for child survival. Journal of health communication, 19(sup1), 216-222.

Wesnes, K. A., Pincock, C., Richardson, D., Helm, G., \& Hails, S. (2003). Breakfast reducesdeclines in attention and memory over the morning in schoolchildren. Appetite, 41(3), 329-331. 